МЕНЕДЖМЕНТ

UDC 510.644.4:519.816 P. M. Hryhoruk, Doctor of Economic Science,
Professor,

N. A. Khrushch, Doctor of Economic Science, Professor,

S. S. Grygoruk, Candidate of Pedagogical Science, Associate Professor

\section{AN APPROACH TO CONSTRUCT FUZZY PREFERENCE RELATIONSHIPS FOR MANAGERIAL DECISION MAKING}

Urgency of the research. The combination of theory and empirical experience of management with modern cognitive tools determines the necessity to use economic and mathematical modeling managerial decision making in conditions of variability, uncertainty and multidimensionality of the market environment.

Target setting. The choice of managerial decision on the set of alternatives is essentially limited to the difficulty of forming a single criterion, which covers different, and in some cases, conflicting requirements. Additional complications are the need to take into account and formalize the uncertainty of both source data and purposes. These lead to the need for use of such models of description of the reality, that allow to process large amounts of data in conditions of the growth of uncertainty.

Actual scientific researches and issues analysis. Tools of fuzzy set theory and fuzzy logic are currently an effective means of formalizing uncertainty in different areas of manager's activities: finance, economics, risk management, marketing and many others. These issues are highlighted in the writings of such scholars as K. Kovalchuk, A. Matviychuk, W.-Y. Cheng, L in, M. Wen, Z. Qin, T. Korol and many others.

Uninvestigated parts of general matters defining. Issues of description of fuzzy preference relationships based on the aggregate of values of several criteria measured in different scales, and development of scientific and methodological approach to select on this basis the set of most suitable alternatives as a decision currently are not solved enough.

The research objective. The main objective of the paper is description of approaches to design fuzzy preference relationships based on the aggregate of values of several criteria measured in different scales, and development of scientific and methodological approach to select on this basis the set of most suitable alternatives as a decision.

The statement of basic materials. The procedure of decision making is considered based on the creation of fuzzy preference relationship with membership function, which reflects the degree of confidence in the superiority of one alternative over another. The choice of alternatives carried out from subset of strictly non-dominated alternatives, based on fuzzy preference relationship.

Conclusions. Given the availability a lot of criteria of effectiveness, the choice of decision should be based on fuzzy preference relationship. The developed scientific and methodological approaches are aimed to construct fuzzy preference relationship for comparison of alternatives on many criteria simultaneously. It allows to manager to form a set of Paretoefficient alternatives and choose from them the best as a decision.
УДК 510.644.4:519.816

\author{
П. М. Григорук, д. е. н., \\ просресор, \\ Н. А. Хрущ, Д. е. Н., \\ професор, \\ С. С. Григорук, к. пед. н., \\ доцент
}

\section{ПІДХІД ДО ПОБУДОВИ НЕЧІТКИХ ВІДНОШЕНЬ ПЕРЕВАГИ В ПРИЙНЯТТІ УПРАВЛІНСЬКИХ РІШЕНЬ}

Актуальність теми дослідження. Поєднання теорії і емпіричного досвіду методів управління із сучасним пізнавальним інструментарієм зумовлює необхідність обгрунтування економіко-математичного моделювання процесів прийняття управлінських рішень в умовах мінливості, невизначеності та багатомірності ринкового середовища.

Постановка проблеми. Вибір управлінського рішення з множини альтернатив істотно обмежується труднощами формування єдиного критерію, який охоплює різні, а в деяких випадках і суперечливі вимоги. Додаткові ускладнення несе необхідність урахування і фоормалізації невизначеності як вихідних даних, так і цільових установок. Ці обставини призводять до необхідності використання таких моделей опису реальності, які дозволяють обробку великих обсягів даних за умов зростання їх невизначеності.

Аналіз останніх досліджень і публікацій. Інструментарій теорії нечітких множин та нечіткої логіки на даний час $\epsilon$ ефективним засобом фоормалізації невизначеності в різних галузях діяльності менеджерів: фрінансах, економіці, ризик-менеджменті, маркетинговій діяльності та багатьох інших. Ці питання висвітлені в працях таких вчених, як К. Ковальчук, А. Матвійчук, У. Ченг, Л. Лін, М. Уен, З. Куін, Т. Корол та багатьох інmux.

Виділення недосліджених частин загальної проблеми. Питання отримання нечіткого відношення переваги на основі сукупності значень декількох критеріїв, виміряних у різних шкалах та розробки науковометодологічного підходу до вибору на їх основі найбільш прийнятних альтернатив в якості управлінського рішення на даний час $є$ недостатньо вирішеними.

Постановка завдання. Метою роботи є опис підходів для отримання нечіткого відношення переваги на основі сукупності значень декількох критеріїв, виміряних у різних шкалах та розробка науково-методологічного підходу до вибору на їх основі в якості рішення найбільш прийнятних альтернатив.

Викладення основного матеріалу. Розглянуто процедуру прийняття рішень на основі побудови нечіткого відношення переваги з фрункцією належності, яка відображає ступінь впевненості в перевазі однієї альтернативи над іншою. Вибір альтернативи здійснюється 3 підмножини строго недомінованих альтернатив, побудованої на основі нечітких відношень переваги.

Висновки відповідно до статmі. За умови наявності багатьох критеріїв ефрективності вибір рішення потрібно здійснювати на основі нечітких відношень пе- 


\section{МЕНЕДЖМЕНТ}

\begin{tabular}{l}
\hline \hline Keywords: Fuzzy set, fuzzy preference relationships; \\
membership function; decision making; non-dominated alter- \\
native; multi-criteria choice.
\end{tabular}

реваги. Розроблені науково-методологічні підходи спрямовані на побудову нечітких відношень переваги для зіставлення альтернатив за багатьма критеріями одночасно. Це дозволяє менеджеру сорормувати множину Парето-ефективних альтернатив $і$ обрати з них найкращу в якості рішення.

Ключові слова: Нечітка множина; нечітке відношення переваги; функція належності; прийняття рішень; недомінована альтернатива; багатокритеріальний вибір.

DOI: 10.25140/2410-9576-2017-2-4(12)-92-99

Urgency of the research. Decision-making is related to the necessity of analyzing and processing large volume of heterogeneous data. But data can be inaccurate, incomplete, can have a high degree of subjectivity in the estimates of the research objects by the respondents and therefore be inconsistent as a result of many factors, such as the imperfection of the measurement procedures, rapid variability of the environment, lack of reliable information on the activities of competitors, consumer behavior and motivation.

Furthermore, use of classical methods to select decisions in the socio-economic systems is significantly limited by the difficulties of forming a single criterion, that includes different, and in some cases contradictory requirements. The human factor has a key role in decision-making, so designing such numerical criteria is enough labor-intensive process, even if it is possible, and in practice generally can be an insoluble issue.

Finally, the most important problem to choice solutions associates with the taking into account and formalizing the uncertainty of the source data and the goals. It should be noted that a significant part of these data can be non-available in a well-defined form, be in the form of non-exact values of objects' attributes, and presented in the form of their approximate or interval estimates, and even can to have a verbal description of quality, that is, to have properties of uncertainty and fuzziness of description. In our view, these circumstances lead to the need for use of such models of description of the reality, that allow to process large amounts of data in conditions of the growth of uncertainty.

Target setting. It is known that effective way to formalize uncertainty is the theory of fuzzy sets and based on it the fuzzy logic, which allow describing imprecise category, views and knowledge, operating them and making appropriate conclusions. It should be noted that elements of human thinking are not numerical objects, but some constructions of fuzzy classes of objects. Traditional methods are not very suitable for the analysis of such systems because they are not able to describe the following features of thinking and behavior. Therefore fuzzy models are more suitable to describe management processes than classic ones.

Actual scientific researches and issues analysis. Currently fuzzy set models are successfully used in taking into account of uncertainty in all areas of management: finance, economics, risk management, insurance, option pricing, investment, marketing, trade, and many others [1-10].

In particular, papers [1-3] considered designing fuzzy regression model to forecast volatility of option prices, evaluate the risk levels of credit applicants, pre-warn financial distress for investors and risk supervisors, make decision about loans. The use of fuzzy logic in designing econometric models to prevent bankruptcy presented in [4-6]. These models are "open" and can be easily used by financial managers as a decision support tool to assist in assessing the financial situation of enterprises and consumers.

In paper [7] authors developed a bi-level fuzzy principal-agent model for optimal nonlinear taxation problems with asymmetric information. This model can be used with the purpose of maximizing the expected social welfare and the monopolist's expected welfare under the incentive feasible mechanism.

A fuzzy attractiveness of market entry model was developed in [8] to address the decision-making problem of product introduction into alternative markets. Model uses expert opinions regarding four factors: fit of the firm's marketing mix in each market; the fit of its key competitor's marketing mix in each market; environmental conditions in each market; and the strategic importance of each market to the firm. 


\section{МЕНЕДЖМЕНТ}

Designing soft decision making models based on intuitionistic fuzzy sets was proposed in papers $[9 ; 10]$. Authors proposed a model for assessing the relative efficiency of a set of congruent decision making units in finance and credit institution.

Paying tribute to these and many other studies on the application of fuzzy logic and fuzzy sets to solve problems in the area of decision-making, it should be noted that some issues related to the selection of an acceptable alternative under multiple criteria remain open.

Uninvestigated parts of general matters defining. The problem of decision-making in the most common formulation is to choose the best alternative from some of the plural. The selection is based on the manager's preference relationship defined on a set of alternatives.

We will understand under the preference the estimation of usefulness or quality of the alternative based on the subjective perception by manager the value and effectiveness of decision. It can be a result of comparing alternatives by the manager in accordance with a generated system of criteria, his intuitive reasoning, a result of the recommendations of the expert group or consultants in decision making. One fairly common approach to estimating the preferences is a paired comparison, having a high degree of objectivity of expert evaluation and independence from criterion's dimension. Thus it is possible to use this approach for both scalar and vector criteria.

Fuzzy preference relationships allow, unlike conventional, to take into account the intensity and force of some preference over other options, therefore the using of such relations as a models of expert data representation allows to improve the adequacy of the description of the system of manager's preference and its sensitivity.

The multiplicity of participants which interested in the obtained results, their aims, and multi-variant of the market environment leads to the possibility of appearance of set of multidirectional criteria for choosing the best solution. Provided that different participants can use different optimal in their opinion, behavior strategies, there is a need for their comparison. However, the issue of designing fuzzy preference relationship with presence of several criteria that measured in different scales are not enough developed.

The research objective. The aim of the article is to describe the procedures for designing fuzzy preference relationships based on the aggregate values of several criteria measured in different scales, scientific and methodological approach to choose on this basis most suitable alternatives.

The statement of basic materials. Decision-making is accompanied by a mandatory procedure for developing and analyzing alternatives.

Taking into account the information uncertainty peculiar to the process, ultimate set of alternatives $A^{(0)}=\left\{A_{1}, A_{2}, \ldots, A_{m}\right\}$ can be described with a certain degree of precision, where $m$ is a number of alternatives. Assume that the fuzzy set $A$ having membership function $\mu_{D}(A)$ that describes the extent of the admissibility of each of the alternative decision given in the original set of $A^{(0)}$. Then, a rational decision can be regarded as a one that will be selected from the subset $A^{(D)}$ of alternatives, with the maximum degree of admissibility:

$$
A^{(D)}=\left\{A_{i} \mid A_{i} \in A, \mu_{D}\left(A_{i}\right)=\max _{j} \mu_{D}\left(A_{j}\right)\right\},
$$

where $i, j=1 . . m$.

Alternative corresponded to the maximum of membership function is non-dominated. However, it is possible to obtain other subset of alternatives to make a choice, if we have more information about such selection. The presented approach does not lead to the desired result in the case of multi-criteria choice when the best decision for some criteria is inferior to others. To take into account all available information on alternatives it is appropriate to consider the preference relation between alternatives.

Fuzzy preference relation can be used to solve this problem of multicriteriality, that have the membership function displays a degree of confidence in the superiority of one alternative over another. It will be given in the form:

$$
P=\left\lfloor A \times A, \mu_{i j}\right\rfloor,
$$

where $A \times A$ is a set of ordered pairs of alternatives; 


\section{МЕНЕДЖМЕНТ}

$\mu_{i j}=\mu\left(A_{i}, A_{j}\right)$ - measure of fuzzy preference relationships showing the extent to which the ordered pair $\left(A_{i}, A_{j}\right)$ corresponds to a clear binary preference relation, consisting in the fact that $A_{i}$ is not worse than $A_{j}$.

The procedure for choosing an alternative as a decision from a fuzzy subset $A^{\text {UND }}$ of strictly nondominated alternatives, which is based on fuzzy preference relationships, is investigated in the paper [11]. Continuing the arguments given in this paper, now we consider procedures for constructing a fuzzy preference relationships $P$ subject to the availability of several criteria. Let's consider first the case when these criteria are measured on one of the metric scales, that is, they are expressed in numerical form. Assume that the set $Q=\left\{Q_{1}, Q_{2}, \ldots, Q_{k}\right\}$ is a set of partial criteria reflects a priori effectiveness of each alternative $A_{i} \in A^{(0)}, i=1,2, \ldots, m$. Let none of the alternatives don't have an absolute preference over other for all criteria simultaneously, that is, one of the alternatives can prevail over the other according to the values of some criteria, and be worse than values of others ones. Without loss of generality, assume that the values of each criterion are normalized, that is, are in the interval $[0 ; 1]$. Then the functions of fuzzy preference relationship $P$ is proposed to construct on a method of maximum difference of the maximum difference, the essence of which is to determine the difference between $A_{i}$ and $A_{j}$ by the maximum advantage of one of the partial criteria. If $i \neq j$ then:

$$
\mu_{i j}=\left\{\begin{array}{ll}
\max _{1 \leq s \leq k} w_{s}\left(Q_{s i}-Q_{s j}\right) \cdot \frac{k_{i j}}{k}, Q_{s i}-Q_{s j} \geq 0 ; \\
0 \quad, Q_{s i}-Q_{s j}<0 .
\end{array},\right.
$$

where $Q_{s t}$ is a value of $s$-th criterion for $t$-th alternative,

$w_{s}$ - weight of $s$-th criterion,

$k_{i j}$ - number of values for $i$-th and $j$-th alternatives, for which the condition $Q_{s i}-Q_{s j} \geq 0$ is met,

$i, j=1,2, \ldots, m, s=1,2, \ldots, k, t=1,2, \ldots, m$.

Value $k_{i j}$ reflects the "potential" of preference of $A_{i}$ over $A_{j}$.

If $i=j$ then value $\mu_{i i}=1$, which corresponds to natural condition that each alternative is not worse itself. That is, we have constructed a fuzzy preference relationships has transitive property.

An alternative method of determining the fuzzy preference relationship $P$ is the average difference method. If $i \neq j$ then:

$$
\mu_{i j}=\left\{\begin{array}{ll}
\sum_{s=1}^{k} w_{s}\left(Q_{i s}-Q_{j s}\right) \cdot \frac{k_{i j}}{k}, & Q_{i s}-Q_{j s} \geq 0 ; \\
0 & , Q_{i s}-Q_{j s}<0 .
\end{array},\right.
$$

where $i, j=1,2, \ldots, m, s=1,2, \ldots, k$.

The weights $w_{s}$ of partial criteria, $s=1,2, \ldots, k$, can be defined by one of the following ways: by experts, on the basis of substantive arguments about the relative importance of the criteria using a priori information.

Now consider the case when each of criteria $Q=\left\{Q_{1}, Q_{2}, \ldots, Q_{k}\right\}$ measured on the rank scale. Let categories of this scale are ordered by increase of quality. Let $\succ$ is a sign of relationships preferences on this scale.

That is, $Q_{s i} \succ Q_{s j}$ means that the value of the $i$-th alternative for $s$-th criterion is not worse than the corresponding value of $j$-th alternatives for the same one, $i, j=1,2, \ldots, m, s=1,2, \ldots, k$.

We propose to construct for each alternative $A_{i}$ a matrix $\tilde{Q}^{(i)}$ with elements determined by the rule: 


\section{МЕНЕДЖМЕНТ}

$$
\tilde{q}_{s j}^{(i)}= \begin{cases}1, & Q_{s i} \succ Q_{s j}, \\ 0, & Q_{s i} \prec Q_{s j} .\end{cases}
$$

Then the membership function can be determined by the formula:

$$
\mu_{i j}=w_{i} \sum_{s} \tilde{q}_{s j}^{(i)},
$$

where components of the formula have the same meaning as before.

Separately consider the case where assessment of preference is carried out by one of noncomparative scales like Likert scale, Stapel scale or semantic differential scale. Then, is it appropriate to draw an analogy between the degree of intensity of allowable of alternative and its location on the scale, linking it with the fuzzy preference relationship. Let $d$ is the range of the scale. Then the value of the function of fuzzy preference relationship is determined by the formula:

$$
\mu_{i j}= \begin{cases}\frac{\sum_{s} w_{s}\left(Q_{s i}-Q_{s j}\right)}{d}, & i \neq j, . \\ 1, & i=j .\end{cases}
$$

Consider practical use presented approach for choice the most appropriate alternatives, provided there are several criteria.

Example. Let we have a matrix of normalized values for eight alternatives assessing by the five metric criteria that presented at the Table 1.

\section{Normalized values for eight alternatives assessing by the five criteria}

Table 1

\begin{tabular}{|c|c|c|c|c|c|}
\hline \multirow{2}{*}{ Alternatives } & \multicolumn{5}{|c|}{ Criteria } \\
\cline { 2 - 6 } & $Q_{1}$ & $Q_{2}$ & $Q_{3}$ & $Q_{4}$ & $Q_{5}$ \\
\hline$A_{1}$ & 0,00 & 0,00 & 0,00 & 0,05 & 0,00 \\
\hline$A_{2}$ & 0,70 & 0,19 & 0,17 & 0,00 & 0,40 \\
\hline$A_{3}$ & 0,50 & 0,22 & 0,67 & 0,14 & 0,60 \\
\hline$A_{4}$ & 0,33 & 0,25 & 1,00 & 1,00 & 0,20 \\
\hline$A_{5}$ & 0,55 & 1,00 & 0,40 & 0,56 & 0,70 \\
\hline$A_{6}$ & 0,63 & 0,95 & 0,20 & 0,86 & 0,60 \\
\hline$A_{7}$ & 0,55 & 0,30 & 0,42 & 0,77 & 1,00 \\
\hline$A_{8}$ & 1,00 & 0,48 & 0,33 & 0,68 & 0,70 \\
\hline
\end{tabular}

Analysis of table shows that none of the alternatives have clear preference on others that predetermines the necessity of additional calculation. Values of membership function of fuzzy preference relationship $\mu_{i j}$ calculated by the method of maximum difference are presented at the table $2, i, j=1$, $2, \ldots, 8$.

Table 2

Values of membership function of fuzzy preference relationship

\begin{tabular}{|c|c|c|c|c|c|c|c|c|}
\hline Alternatives & $A_{1}$ & $A_{2}$ & $A_{3}$ & $A_{4}$ & $A_{5}$ & $A_{6}$ & $A_{7}$ & $A_{8}$ \\
\hline$A_{1}$ & 0,00 & 0,01 & 0,00 & 0,00 & 0,00 & 0,00 & 0,00 & 0,00 \\
\hline$A_{2}$ & 0,56 & 0,00 & 0,04 & 0,15 & 0,03 & 0,02 & 0,03 & 0,00 \\
\hline$A_{3}$ & 0,67 & 0,40 & 0,00 & 0,16 & 0,05 & 0,19 & 0,05 & 0,07 \\
\hline$A_{4}$ & 1,00 & 0,60 & 0,51 & 0,00 & 0,24 & 0,32 & 0,23 & 0,27 \\
\hline$A_{5}$ & 1,00 & 0,65 & 0,62 & 0,45 & 0,00 & 0,12 & 0,28 & 0,31 \\
\hline$A_{6}$ & 0,95 & 0,69 & 0,58 & 0,42 & 0,12 & 0,00 & 0,39 & 0,19 \\
\hline$A_{7}$ & 1,00 & 0,62 & 0,50 & 0,48 & 0,24 & 0,16 & 0,00 & 0,18 \\
\hline$A_{8}$ & 1,00 & 0,68 & 0,43 & 0,41 & 0,27 & 0,23 & 0,18 & 0,00 \\
\hline
\end{tabular}




\section{МЕНЕДЖМЕНТ}

Using the values of Table 2, in accordance with [11] we calculate a membership function of fuzzy strict preference relationship $\mu_{i j}^{s}$. Results are shown at the Tab. 3 .

Table 3

Values of membership function of fuzzy strict preference relationship

\begin{tabular}{|c|c|c|c|c|c|c|c|c|}
\hline Alternatives & $A_{1}$ & $A_{2}$ & $A_{3}$ & $A_{4}$ & $A_{5}$ & $A_{6}$ & $A_{7}$ & $A_{8}$ \\
\hline$A_{1}$ & 0,00 & 0,00 & 0,00 & 0,00 & 0,00 & 0,00 & 0,00 & 0,00 \\
\hline$A_{2}$ & 0,55 & 0,00 & 0,00 & 0,00 & 0,00 & 0,00 & 0,00 & 0,00 \\
\hline$A_{3}$ & 0,67 & 0,36 & 0,00 & 0,00 & 0,00 & 0,00 & 0,00 & 0,00 \\
\hline$A_{4}$ & 1,00 & 0,45 & 0,35 & 0,00 & 0,00 & 0,00 & 0,00 & 0,00 \\
\hline$A_{5}$ & 1,00 & 0,62 & 0,57 & 0,21 & 0,00 & 0,00 & 0,04 & 0,04 \\
\hline$A_{6}$ & 0,95 & 0,67 & 0,40 & 0,10 & 0,00 & 0,00 & 0,23 & 0,00 \\
\hline$A_{7}$ & 1,00 & 0,59 & 0,45 & 0,25 & 0,00 & 0,00 & 0,00 & 0,00 \\
\hline$A_{8}$ & 1,00 & 0,68 & 0,36 & 0,14 & 0,00 & 0,04 & 0,00 & 0,00 \\
\hline
\end{tabular}

Further we construct a membership function of fuzzy set of non-dominated alternatives $\mu^{N D}$ (Tab. 4) and determine subset of strictly non-dominated alternatives.

Values of membership function of fuzzy set of non-dominated alternatives

Table 4

\begin{tabular}{|c|c|c|c|c|c|c|c|}
\hline \multicolumn{7}{|c|}{ Alternatives } \\
\hline$A_{1}$ & $A_{2}$ & $A_{3}$ & $A_{4}$ & $A_{5}$ & $A_{6}$ & $A_{7}$ & $A_{8}$ \\
\hline 0,00 & 0,32 & 0,43 & 0,75 & 1,00 & 0,96 & 0,77 & 0,96 \\
\hline
\end{tabular}

Tab. 4 shows that in this case subset $A^{U N D}$ has only single alternative $-A_{5}$, which should be choose as a decision. At the same time, it should also be noted high value of membership functions for the sixth and eighth alternatives. If assessing alternatives have realized by the first four criteria, then values of membership functions $\mu_{i j}, \mu_{i j}^{s}, \mu_{i}^{N D}$ be in the other form (Tables 5-7)

Table 5

Values of membership function of fuzzy preference relationship for four criteria

\begin{tabular}{|c|c|c|c|c|c|c|c|c|}
\hline Alternatives & $A_{1}$ & $A_{2}$ & $A_{3}$ & $A_{4}$ & $A_{5}$ & $A_{6}$ & $A_{7}$ & $A_{8}$ \\
\hline$A_{1}$ & 0,00 & 0,01 & 0,00 & 0,00 & 0,00 & 0,00 & 0,00 & 0,00 \\
\hline$A_{2}$ & 0,53 & 0,00 & 0,05 & 0,09 & 0,04 & 0,02 & 0,04 & 0,00 \\
\hline$A_{3}$ & 0,67 & 0,38 & 0,00 & 0,04 & 0,07 & 0,12 & 0,06 & 0,08 \\
\hline$A_{4}$ & 1,00 & 0,75 & 0,64 & 0,00 & 0,30 & 0,40 & 0,29 & 0,34 \\
\hline$A_{5}$ & 1,00 & 0,61 & 0,58 & 0,38 & 0,00 & 0,10 & 0,35 & 0,26 \\
\hline$A_{6}$ & 0,95 & 0,64 & 0,55 & 0,35 & 0,15 & 0,00 & 0,49 & 0,23 \\
\hline$A_{7}$ & 0,72 & 0,58 & 0,47 & 0,11 & 0,16 & 0,05 & 0,00 & 0,05 \\
\hline$A_{8}$ & 1,00 & 0,68 & 0,40 & 0,34 & 0,23 & 0,19 & 0,23 & 0,00 \\
\hline
\end{tabular}

Values of membership function of fuzzy strict preference relationship for four criteria

\begin{tabular}{|c|c|c|c|c|c|c|c|c|}
\hline Alternatives & $A_{1}$ & $A_{2}$ & $A_{3}$ & $A_{4}$ & $A_{5}$ & $A_{6}$ & $A_{7}$ & $A_{8}$ \\
\hline$A_{1}$ & 0,00 & 0,00 & 0,00 & 0,00 & 0,00 & 0,00 & 0,00 & 0,00 \\
\hline$A_{2}$ & 0,51 & 0,00 & 0,00 & 0,00 & 0,00 & 0,00 & 0,00 & 0,00 \\
\hline$A_{3}$ & 0,67 & 0,32 & 0,00 & 0,00 & 0,00 & 0,00 & 0,00 & 0,00 \\
\hline$A_{4}$ & 1,00 & 0,66 & 0,60 & 0,00 & 0,00 & 0,05 & 0,18 & 0,00 \\
\hline$A_{5}$ & 1,00 & 0,57 & 0,52 & 0,08 & 0,00 & 0,00 & 0,19 & 0,03 \\
\hline$A_{6}$ & 0,95 & 0,62 & 0,43 & 0,00 & 0,05 & 0,00 & 0,44 & 0,05 \\
\hline$A_{7}$ & 0,72 & 0,54 & 0,41 & 0,00 & 0,00 & 0,00 & 0,00 & 0,00 \\
\hline$A_{8}$ & 1,00 & 0,68 & 0,32 & 0,00 & 0,00 & 0,00 & 0,18 & 0,00 \\
\hline
\end{tabular}

Analysis results presented in the Table 7 shows that subset $A^{\text {UND }}$ is empty. Therefore it is need to define subset of $r^{*}$ - non-dominated alternatives. In this case we have a result: $r=0,95$; $A^{\mathrm{UND}}(0,95)=\left\{A_{5}, A_{6}, A_{8}\right\}$. 
МЕНЕДЖМЕНТ

Values of membership function of fuzzy set of non-dominated alternatives for four criteria

Table 7

\begin{tabular}{|c|c|c|c|c|c|c|c|}
\hline \multicolumn{7}{|c|}{ Alternatives } \\
\hline$A_{1}$ & $A_{2}$ & $A_{3}$ & $A_{4}$ & $A_{5}$ & $A_{6}$ & $A_{7}$ & $A_{8}$ \\
\hline 0,00 & 0,32 & 0,40 & 0,92 & 0,95 & 0,95 & 0,56 & 0,95 \\
\hline
\end{tabular}

Conclusions. Summing up the presented reasoning, we propose the following methodical approach to choosing the most suitable alternative.

1. An initial set of alternatives $A^{(0)}=\left\{A_{1}, A_{2}, \ldots, A_{m}\right\}$ is constructed.

2. Constructing a set of partial effectiveness criteria $Q=\left\{Q_{1}, Q_{2}, \ldots, Q_{k}\right\}$ is carried out.

3. For each pair of alternatives $\left(A_{i}, A_{j}\right)$ value of membership function $\mu_{i j}=\mu\left(A_{i}, A_{j}\right)$ of fuzzy preference relationship is calculated, which reflects the degree of preference alternative $A_{i}$ over alternative $A_{j}$. With that end in view one or some formulas (3)-(7) are used depending on the type of criteria and method their assessment.

4. In accordance with [11], a fuzzy strict preference relationship $P^{s}$, fuzzy subset of nondominated alternatives $A^{N D}$ and fuzzy subset of strictly non-dominated alternatives $A^{U N D}$ is constructed. Optimal decision is chosen from this subset as any of its alternatives.

5. If subset $A^{U N D}$ is empty, we define a subset of $r$-non-dominated alternatives.

This approach allows, in practice, to design the set of Pareto-effectiveness alternatives and to choose the best one of them as a decision. If we have several alternatives of this kind, we should make a choice based on additional reasoning, in particular, using expert judgments, analysis of nonprice indices of effectiveness, applying the criterion of minimization of charges and so on.

\section{References}

1.Kovalchuk, K. F. \& Nykytenko, O. K. (2012). Rozrobka modeli upravlinnia finansovymy instrumentamy na rynku z vykorystanniam metodu nechitkoi aproksymatsii [Designing a model for management of financial tools on market with the use of method of the fuzzy approximation]. Neiro-nechitki tekhnolohii modeliuvannia $v$ ekonomitsi - Neural simulation technology in the economy, 1, 161-170 [in Ukrainian].

2.Cheng, W.-Y., Ender, S. \& Sheng-Jung, L. A. (2006) Financial distress pre-warning study by fuzzy regression model of TSE-listed Companies. Asian Academy of Management Journal of Accounting and Finance. Retrieved from http://web.usm.my/journal/aamjaf/vol\%202-2/2-2-5.pd English]

3.Muzzioli, S., Ruggieri, A. \& De Baets B. (2015). A comparison of fuzzy regression methods for the estimation of the implied volatility smile function. Fuzzy Sets and Systems, 266, 131-143 [in English]

4.Matviichuk, A. V. (2012). Shtuchnyi intelekt $v$ ekonomitsi: neironni merezhi, nechitka lohika [Artificial intelligence in the economy: neural networks, fuzzy logic]. Kyiv: Kyivskyi Natsionalnyi Ekonomichnyi Universytet ineni Vadyma Hetmana [in Ukrainian].

5.Korol, T. (2012). Fuzzy logic in financial management. Retrieved from: http://cdn.intechopen.com/pdfswm/32889.pdf [in English].

6.Starchenko, L. V., Starovoit, O. V. \& Semydotska, I. I. (2012). Vykorystannia metodu nechitkykh mnozhyn dlia diahnostyky ryzyku bankrutstva pidpryiemstva [Using the method of fuzzy sets for diagnostics of the risk of enterprise bankruptcy]. Mekhanizm rehuliuvannia ekonomiky - Mechanism of Economic Regulation, 3, 83-91 [in Ukrainian].

7.Lan, Y., Zhao, R. \& Tang, W. (2011). A bilevel fuzzy principal-agent model for optimal nonlinear taxation prob-

\section{Література}

1.Ковальчук, К. Ф. Розробка моделі управління фінансовими інструментами на ринку з використанням методу нечіткої апроксимації / К. Ф. Ковальчук, О. К. Никитенко // Нейро-нечіткі технології моделювання в економіці. 2012. - № 1. -161-170.

2. Cheng, W.-Y. Financial distress pre-warning study by fuzzy regression model of TSE-listed Companies [Electronic resource] / W.-Y. Cheng, S. Ender, L. A. Sheng-Jung // Asian Academy of Management Journal of Accounting and Finance. - 2006 - Retrieved from http://web.usm.my/journal/aamjaf/vol\%202-2/2-2-5.pdf.

3.Muzzioli, S. A comparison of fuzzy regression methods for the estimation of the implied volatility smile function / S. Muzzioli, A. Ruggieri, B. De Baets // Fuzzy Sets and Systems. - 2015. - № 266. - 131-143.

4.Матвійчук, А. В. Штучний інтелект в економіці: нейронні мережі, нечітка логіка : монографрія / А. В. Матвійчук. - К. : КНЕУ, 2011. - 439c.

5. Korol, T. "Fuzzy logic in financial management" [Electronic resource]. - 2012. - Retrieved from: http://cdn.intechopen.com/pdfs-wm/32889.pdf.

6.Старченко, Л. В. Використання методу нечітких множин для діагностики ризику банкрутства підприємства / Л. В. Старченко, О. В. Старовойт, І. І. Семидоцька // Механізм регулювання економіки. - 2012. - № 3. - 83-91.

7.Lan, Y. A bilevel fuzzy principal-agent model for optimal nonlinear taxation problems / Y. Lan, R. Zhao, W. Tang // Fuzzy Optimization and Decision Making. - 2011. - № 10 (3). - P. 211-232.

8. Shipley, M. F. A fuzzy attractiveness of market entry (FAME) model for market selection decisions / M. F. Shipley, M. Johnson, L. Pointer, N. Yankov // Journal of the Operational Research Society. - 2013. - № 64. - P. 597-610. 


\section{МЕНЕДЖМЕНТ}

lems. Fuzzy Optimization and Decision Making, 10(3), 211232 [in English].

8.Shipley, M. F., Johnson, M., Pointer, L., \& Yankov N. (2013). A fuzzy attractiveness of market entry (FAME) model for market selection decisions. Journal of the Operational Research Society, 64, 597-610 [in English].

9.Lin, L., Yuan, X.-H. \& Xi, Z.-Q. (2007). Multicriteria fuzzy decision-making methods based on intuitionistic fuzzy sets. Journal of Computer and System Sciences, 73(1), 8488 [in English].

10. Wen, M., Qin, Z. \& Kang, R. (2011). Sensitivity and stability analysis in fuzzy data envelopment analysis. Optimization and Decision Making, 10(1), 1-10 [in English].

11. Orlovski, S. (1978). Decision-making with a fuzzy preference relation. Fuzzy Sets and Systems, 1(3), 155-168 [in English].

\section{Бібліографічний опис для цитування :}

Hryhoruk, P. M. An approach to construct fuzzy preference relationships for managerial decision making / P. M. Hryhoruk,

N. A. Khrushch, S. S. Grygoruk // Науковий вісник Полісся. - 2017. - № 4 (12). 4 2. - С. 92-99.
9. Lin, L. Multicriteria fuzzy decision-making methods based on intuitionistic fuzzy sets / L. Lin, X.-H. Yuan, Z.-Q. Xi // Journal of Computer and System Sciences. - 2007. № 73 (1). - P. 84-88.

10. Wen, M. Sensitivity and stability analysis in fuzzy data envelopment analysis / M. Wen, Z. Qin, R. Kang // Optimization and Decision Making. - 2011. - № 10(1). - P. 1-10.

11. Orlovski, S. Decision-making with a fuzzy preference relation / S. Orlovski // Fuzzy Sets and Systems. - 1978. № 1(3). - P. 155-168. 